$2^{\text {nd }}$ European Conference on Polygeneration $-30^{\text {th }}$ March- $1^{\text {st }}$ April, 2011- Tarragona, Spain Francisco Javier PINO, Rosario CARO, Juan Rafael LÓPEZ, Felipe ROSA, José GUERRA Experimental validation of an optical and thermal model of a Linear Fresnel Collector

\title{
Experimental validation of an optical and thermal model of a Linear Fresnel Collector
}

\author{
Francisco Javier PINO $^{(a)}$, Rosario CARO ${ }^{(a)}$, Juan Rafael LÓPEZ ${ }^{(b)}$, Felipe ROSA $^{(a)}$, \\ José GUERRA ${ }^{(a)}$ \\ (a) Termotecnia Group, Energy Department, Engineering School, University of Seville, \\ Camino de los Descubrimientos S/N, 41092, Seville. \\ (b) A.I.C.I.A., Engineering School, Camino de los Descubrimientos S/N, 41092, Seville.
}

\begin{abstract}
This paper describes the design and validation of a solar powered Fresnel collector model. The function of the model is to simulate the optical and thermal dynamics of a Fresnel water heating system. The model is validated using real data gathered from a cooling plant with double effect absorption chiller located in the Engineering Schoolf of the University of Seville, Spain. Comparison of calculated and plant measured data shows that the error is lower than $3 \%$ in the optical model and within $7 \%$ in the thermal model.

The model uses a new approach to include a solar tracking mirror mechanism in one axis. This tracking has been designed to maximise the reception of available solar radiation received by the inverted collector pipe. The thermal model used is based around classical models for solar receivers with experimental results compared with real operating plant data.

The Fresnel model has been designed with sufficient flexibility to allow system design change modelling, plant position and operation analysis, and may be used to simulate the performance of a proposed Fresnel collector system at any location.
\end{abstract}

\section{Keywords}

FRESNEL collector, optical model, thermal model, solar cooling, experimental data.

\section{Introduction}

The objective of the work presented in this paper is to simulate the performance of a solar plant with Fresnel collectors using the combination of optical and thermal modelling. Results from the theoretical model are validated with data gathered from an experimental plant.

The optical model developed in this paper brings a new approach to others published optical models that are made by ray-tracing [1] or for a collector with two-axis tracking [2], where sun rays are perpendicular to collector surface. In this model a collector with tracking mechanism in one axis only is studied, so that each collector row is positioned with the objective of reflecting the solar radiation to a pipe. The thermal model for reception pipe is similar to others that have been published in several papers [1, 3-8].

A solar refrigeration plant has been erected in Engineering School of Seville as a long-term project in partnership with "Gas Natural" to facilitate the integration of both solar energy and natural gas in refrigeration applications. The objective of this work is to identify design 
improvements for future plants and to serve as a guideline, where the solar collector size and shades, climatology, heat losses, operation control and coupling between chiller and solar collector are the most masterful aspects. The solar collector is coupled with a double-effect $\mathrm{LiBr}+$ water absorption chiller of $174 \mathrm{~kW}$ nominal cooling capacity with an auxiliary natural gas burner. Financial support for this work was provided by Gas Natural SDG Company, with the participation of AICIA and supported by Corporación Tecnológica de Andalucía. [9]

The solar facility is located on the roof of the building at the Engineering School of Seville. The general geographical coordinates of the system are $37.41^{\circ}$ latitude and $6.00^{\circ}$ longitude West. Solar field has a deviation of $12^{\circ} 3$ ' 1 "' W respect the South, and rows axis orientation is East - West. The total collector area is $352 \mathrm{~m} 2$ and distributed over 11 rows of primary reflectors. The total number of reflectors is 176, with 16 reflectors in each row. A picture of the solar facility is shown in Figure 1 (left).
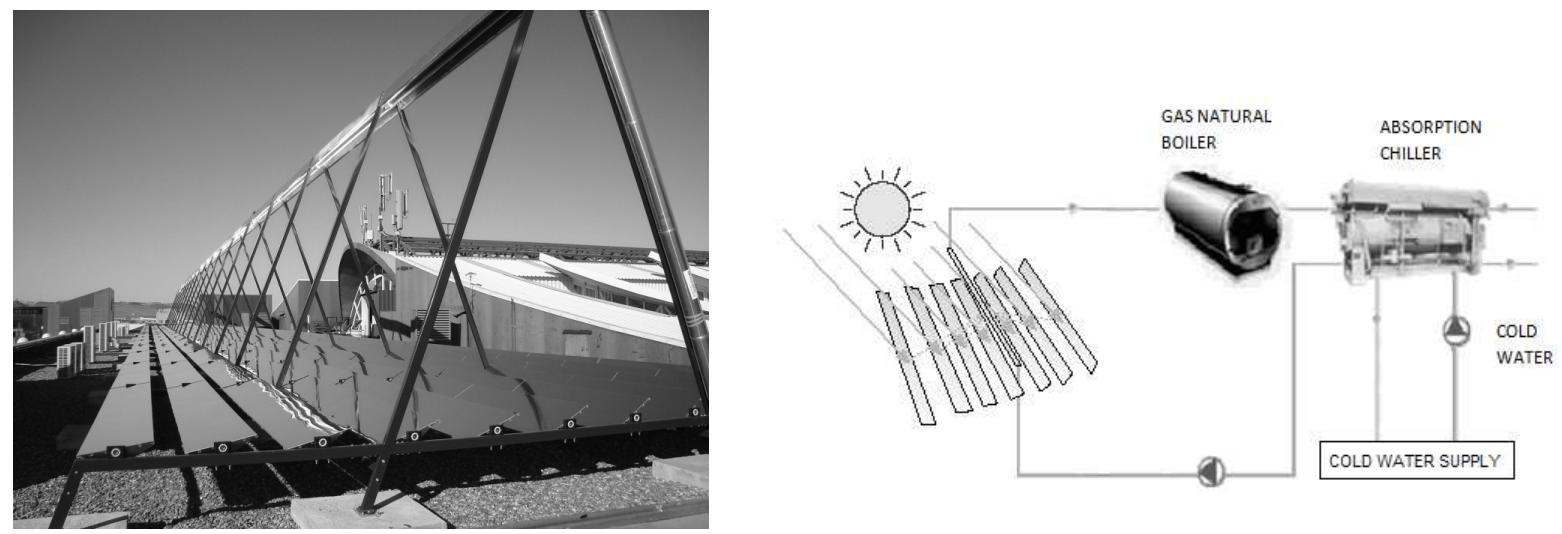

Figure 1. Left: General outlook of the FRESNEL collector, right: General diagram of solar cooling plant with the absorption chiller

Primary mirrors are made of glass and they are lightly elastically curved (with a curvature radius between $8.6-10.6 \mathrm{~m}$ ) and they have a nominal reflectance of 0.92 [10]. They are moved by a solar tracking system working in an autonomous way with an electric motor. Each dragging mechanism moves eight mirrors in each row. Each row is separated by a spacing of $20 \mathrm{~cm}$ to the next row to allow for a rotative angle of $180^{\circ}$.

The secondary reflector on the top side of the receiver consists of a metallic thin wrapper and a polished aluminium layer (nominal reflectance: 0.77). Its objective is to reflect rays to the reception pipe from primary mirrors. In this way the optical efficiency of the system is optimized. The secondary reflector also protects the receptor pipe from wind, rain and dirtiness [10].

The reception pipe SCHOTT PTR $® 70$ is composed of an absorption pipe and a glass envelope which ensures the vacuum between both. It is placed four meters over the mirror axis and it has a length of 64 meters. The absorption pipe is made of stabilized austenitic stainless steel DIN 1.4541 and it has a nominal absorptance of 0.94 . Water temperature is limited to a maximum of $200{ }^{\circ} \mathrm{C}$ and the pressure is limited to a maximum of 16 bar. The nominal water flow rate is $13 \mathrm{~m}^{3} / \mathrm{h}$ at a nominal operational pressure of 13 bar. The safety pressure relief valve is set to 16 bar to protect the system from over pressurization. The water flow rate can change depending on operation conditions $[11,14]$.

The absorption chiller is a BROAD BZH15. Its maximum cooling power is $174 \mathrm{~kW}$ with a nominal coefficient of performance (COP) of 1.3, and the temperature in the generator is $145^{\circ} \mathrm{C}$. Hot water which comes in the absorption chiller is heated by Fresnel collectors and an 
$2^{\text {nd }}$ European Conference on Polygeneration $-30^{\text {th }}$ March $-1^{\text {st }}$ April 2011 - Tarragona, Spain auxiliary system (as auxiliary unit) composed by a natural gas burner. A general diagram of the plant is shown in Figure 1 (Right).

This paper has been divided into four sections. Firstly, in section 1, the optical model is explained, as its results are necessary for the thermal model, presented in section 2. In section 3 , the experimental plant located in the School of Engineering University of Seville (Spain) is briefly described, and a comparison is made between real data and model results. Final conclusions of study are discussed in section 4 .

The diagram of the Fresnel collector plant being modelled is shown in Figure 2, as well as the system coordinates used in the model. The plant has three main parts: the first part consists of the 11 rows of mirrors located at the lower end of the collector. These mirrors have one axis of rotation. Incident radiation is reflected by the mirrors to the receiver located at the highest point, which is the second part (receiver is composed by a secondary reflector and a reception pipe). Heat energy is gathered from the pipe using a continuous working fluid.
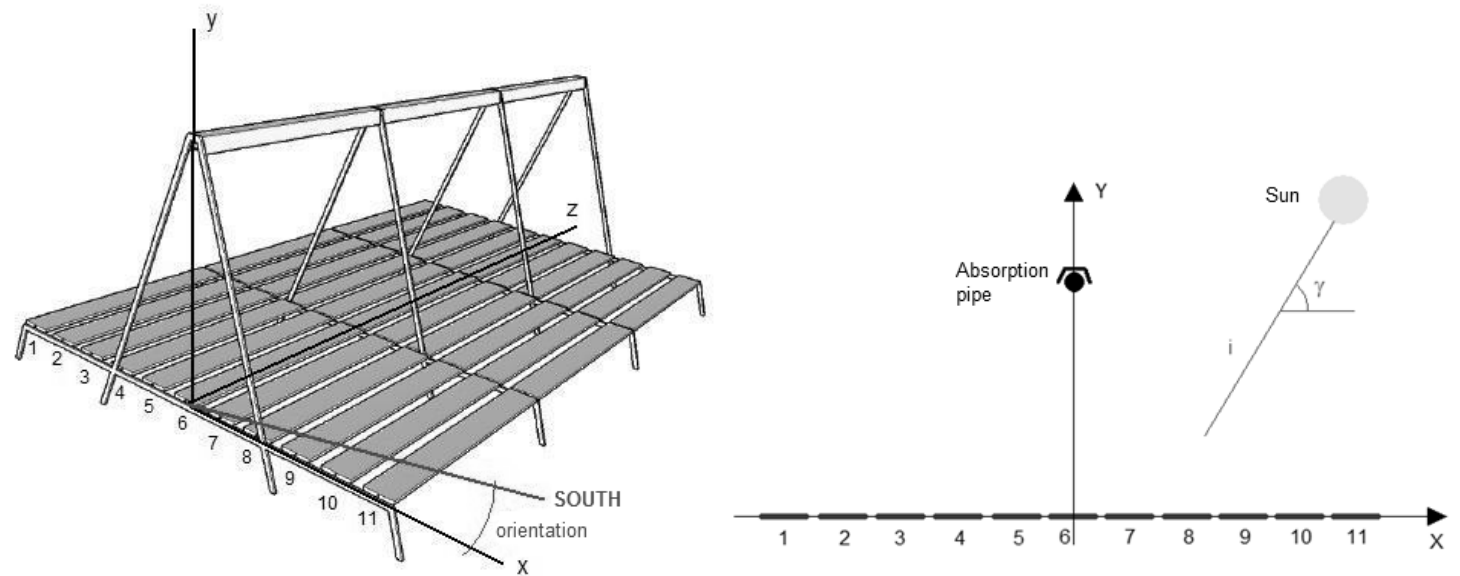

Figure 2. Reference axis, mirrors rows nomenclature and solar field orientation.

\section{Optical model}

The main objective of the optical model is to calculate the solar power leaving the mirror using solar beam on the mirror. The calculated solar radiation is an input parameter for thermal model. The model also calculates all the optical parameters of the primary collector system such as: mirror rows inclination, shadowing between rows, cosine factor losses, etc. Matlab is used to solve optical model whose input and output parameters are shown in Table 1.

\begin{tabular}{|l|l|}
\hline MODEL INPUTS & MODEL OUTPUTS \\
\hline $\begin{array}{l}\text { Day of the year, from 1 to 365 } \\
\text { (number 1 is the First of January) }\end{array}$ & - Solar position \\
- Local time (hours) & - Solar time \\
- Direct solar radiation $\left(\mathrm{W} / \mathrm{m}^{2}\right)$ & Inclination of the mirrors rows \\
- Orientation of solar collector axis & - Shadows between rows \\
respect South & - Stretch and percentage of non- \\
& $\begin{array}{l}\text { illuminated pipe } \\
\text { Optical losses factor }\end{array}$ \\
& $\begin{array}{l}\text { Real radiation from the mirrors to the } \\
\text { receptor pipe } \\
\text { Theoretical radiation without losses }\end{array}$ \\
\hline
\end{tabular}

Table 1. Input and output parameters for the optical model 
The block diagram of the model is shown in Figure 3. The model has been developed in two parts to reflect each of the subsystems within the plant. The two-dimensional optical model is used to calculate the position of the mirrors and the shading between rows. The threedimensional thermal model is used to model both the radiant energy received by the pipe from the mirror rows as well as the heat transfer to the working fluid. Each models are described below.

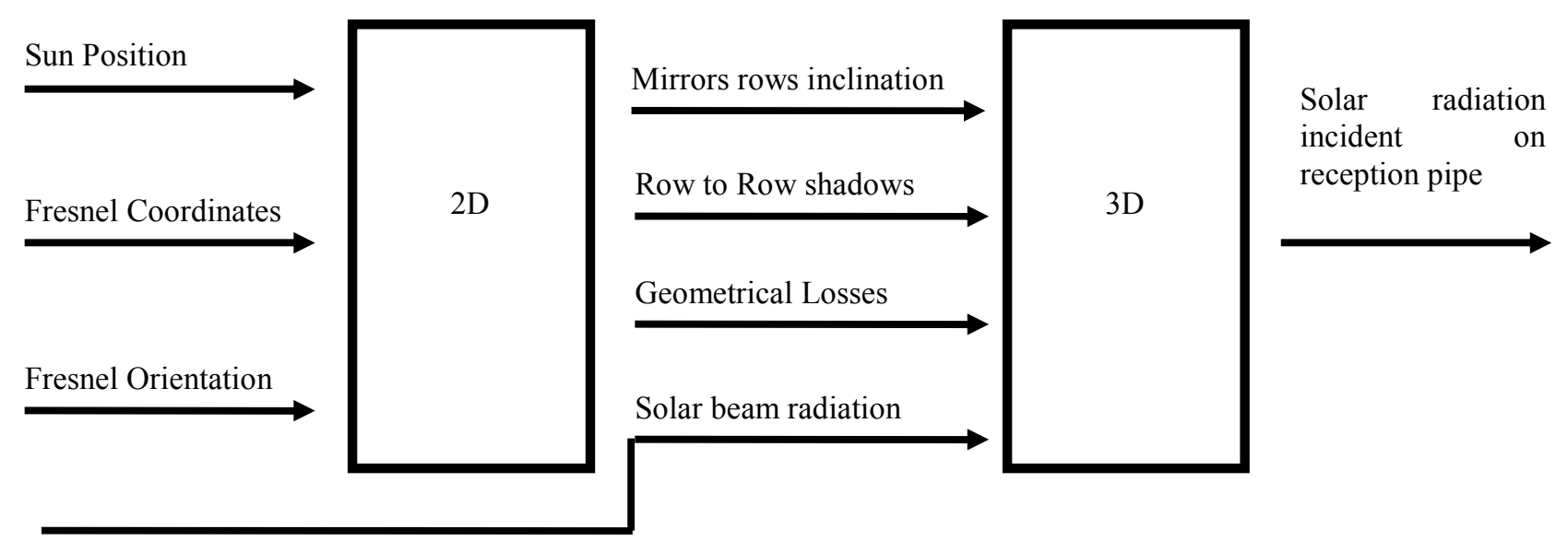

Figure 3. Block diagram of optical model for a Fresnel collector.

\subsection{Two dimensional optical model (2D model)}

By using system coordinates and geometric data for the system, the position of eleven mirror rows at a particular day and at a particular hour are calculated. The solar incidence vector is projected on $\mathrm{X}$ and $\mathrm{Y}$ axes (Figure 1) at each time step, with the final goal to calculate inclination of the mirror as result of solar tracking.

Primary mirrors are assumed flat as the radius of curvature is large, and calculations for the mirror rows inclination are made by using the central point of each mirror row.

The solar incidence vector has the following expressions:

$$
\vec{i}=\left[\begin{array}{c}
\cos (E l e) \cdot \cos (-A z i+\text { Orientation }) \\
\sin (\text { Ele }) \\
\cos (\text { Ele }) \cdot \sin (-A z i+\text { Orientation })
\end{array}\right]
$$

Solar parameters are calculated as a function of the local solar time and system coordinates while a set of astronomic equations are used to calculate the sun position at any moment [9]. Main angles and vectors associated with mirror tracking used for calculation purposes are presented in Figure 4. 


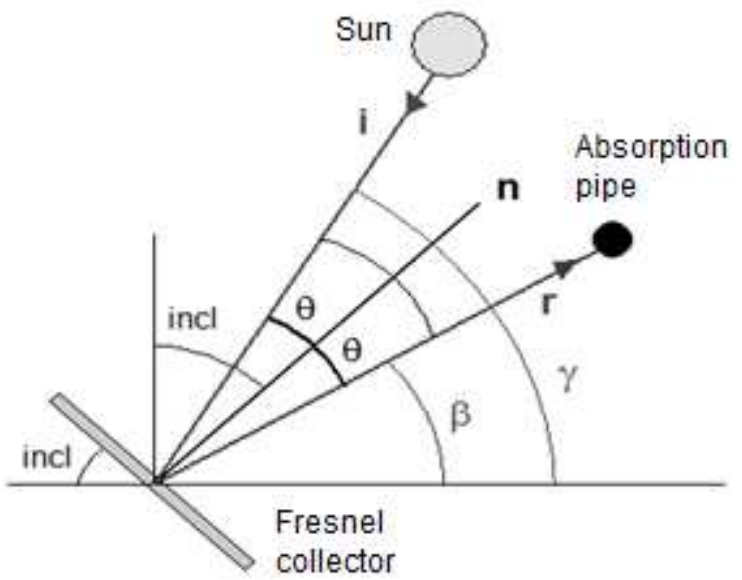

Figure 4. Two-dimensional diagram of a Fresnel mirror row and associated parameters.

\subsubsection{Inclination of mirror rows}

Inclination of each mirrors row is calculated by taking into account: solar incidence vector, row position on $\mathrm{X}$ and $\mathrm{Y}$ axes and reception tube position (Figure 4). By taking into account the law of reflection in a mirror, on each mirror row, angle $(\theta)$ between incidence solar vector (i) and surface normal vector (n) must be equal to angle between reflected solar vector (r) and surface normal vector (n). In Figure 3, all angles and vectors are shown.

Trigonometry is used to calculate the inclination angle (incl). It depends on the position of mirror row on the $\mathrm{X}$ axis. Inclination angle is positive according to the direction shown in Figure 5.

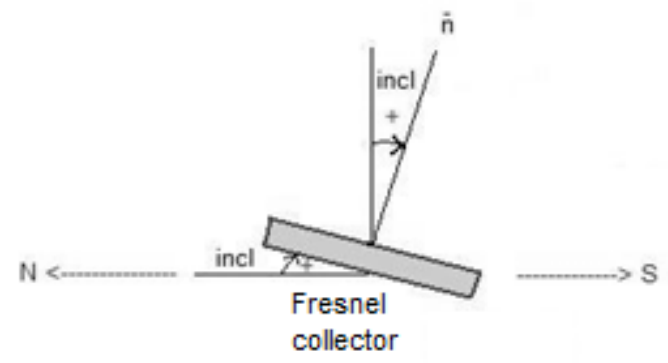

Figure 5. Positive direction for the mirrors rows inclination

\subsubsection{Shadowing between rows}

Shadowing between mirrors rows are calculated by using a two-dimensional model. It is assumed that the Sun's azimutal component is not significant in the value of shading between rows, due to the high length of the solar field. The possible shadow produced by a row on the next row to South, due to solar position, is calculated. There are three cases according to positive or negative inclination of the mirrors. Case 1: inclination of row considered is positive and next row has also positive inclination. Case 2: inclination of row considered is positive and next row has negative. Case 3: inclination of row considered is negative and next row has also negative inclination (in this case, shading between rows is not produced).

This procedure is applied to all rows (except last row which does not have any shadow from mirrors field). The total shaded area is calculated. This area is divided by the total reflection area to get the shading ratio. This ratio affects the total radiation that will arrive at the reception pipe, so it is necessary to define a shading factor in this way: 
$2^{\text {nd }}$ European Conference on Polygeneration $-30^{\text {th }}$ March $-1^{\text {st }}$ April 2011 - Tarragona, Spain

$$
\text { shading ratio }=\frac{\text { shady ara }}{\text { total ara }} \rightarrow f_{\text {shading }}=1-\text { shading ratio (eq. } 2 \text { ) }
$$

\subsubsection{Optical losses}

With reference to Figure 4 it is clear that the angle $\theta$ would be zero for minimum optical losses, but this would correspond to the pipe lying in the path between the sun and the mirror surface, which is not realistic. So, there is a loss in the effective area of each mirror which is quantified by the angle $\delta$. This angle, formed by the real position of the mirror and the position that the mirror should have when it is perpendicular to the incident radiation is used in order to define the effective row area.

\subsection{Three-dimensional optical model (3D model)}

When the inclination of each mirror row is known, the length of the absorption pipe not illuminated due to solar azimutal component needs to be calculated instantaneously (Figure 4). This affects the incident radiation on the pipe and a three-dimensional model including solar azimutal component is then used.

The coordinate axes in this model are shown in Figure 4. The three components of solar incidence vector have to be considered.

According to the coordinate system defined, the normal vector to each mirror is:

$$
\vec{n}=\left[\begin{array}{c}
\sin (i n c l) \\
\cos (i n c l) \\
0
\end{array}\right]
$$

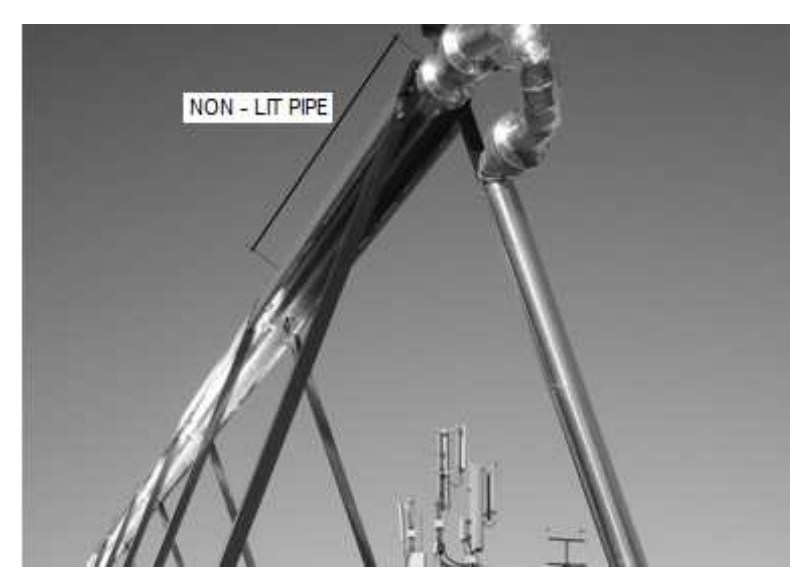

Figure 4. Non - lit pipe due to azimuth.

By taking into account the law of reflection in a mirror, it is known that the incidence angle equals the reflection angle. So the following equality between vectorial products must come true:

$$
\vec{\imath} x \vec{n}=\vec{n} x \vec{r} \text { (eq. 4) }
$$

Vector $\vec{r}$ is the reflection of the solar ray as it goes into the reception pipe. With equation 4, non-lite pipe is calculated for each mirrors row. With these, a correction factor is calculated:

$$
f_{\text {nip_row }}=\frac{\text { Total length-No lit pipt } \theta_{\text {Taw }}}{\text { Total length }}(\text { eq. 5) }
$$




\subsection{Incident power on absorber}

The incident power on the absorber from each mirror row is calculated according to the following equation:

$$
\left.I A_{\text {row }}=B R \cdot A_{\text {row }} \cdot \cos \left(\delta_{\text {row }}\right) \cdot f_{\text {nlp row }} \cdot\left(\rho_{\text {pr }} \cdot f_{d l-p r}\right) \text { (eq. } 6\right)
$$

The total power incident on the absorption tube is calculated from the addition of radiation for all rows multiplied by the shading factor, the absorptance of the secondary reflector and the dirtiness loss factor of the secondary reflector.

$$
Q_{\text {ine }}=\sum_{j=1}^{j=11} I A_{\text {row } j} \cdot f_{\text {shading }} \cdot\left(\rho_{s r} \cdot f_{d l-s r}\right) \quad \text { (eq. 7) }
$$

\section{Thermal model}

The objective of this model is to calculate all thermal parameters including power, flow rates and plant temperatures. The main parameters calculated are output temperature of water and power absorbed at different water flow rates. For comparison and validation purposes, these values can be measured experimentally from the experimental plant. Commercial computer program Engineering Equation Solver (EES) is used to solve this model. Geometric data of absorption pipe, glass envelope and secondary reflector are known and need to be programmed into the model $[9,12]$.

Classic heat transfer models $[10,12]$ are used to solve thermal problem of a system composed by reception pipe and secondary reflector. Figure 5 (left and right) shows all power flows for the thermal model of reception pipe and secondary receptor respectively.
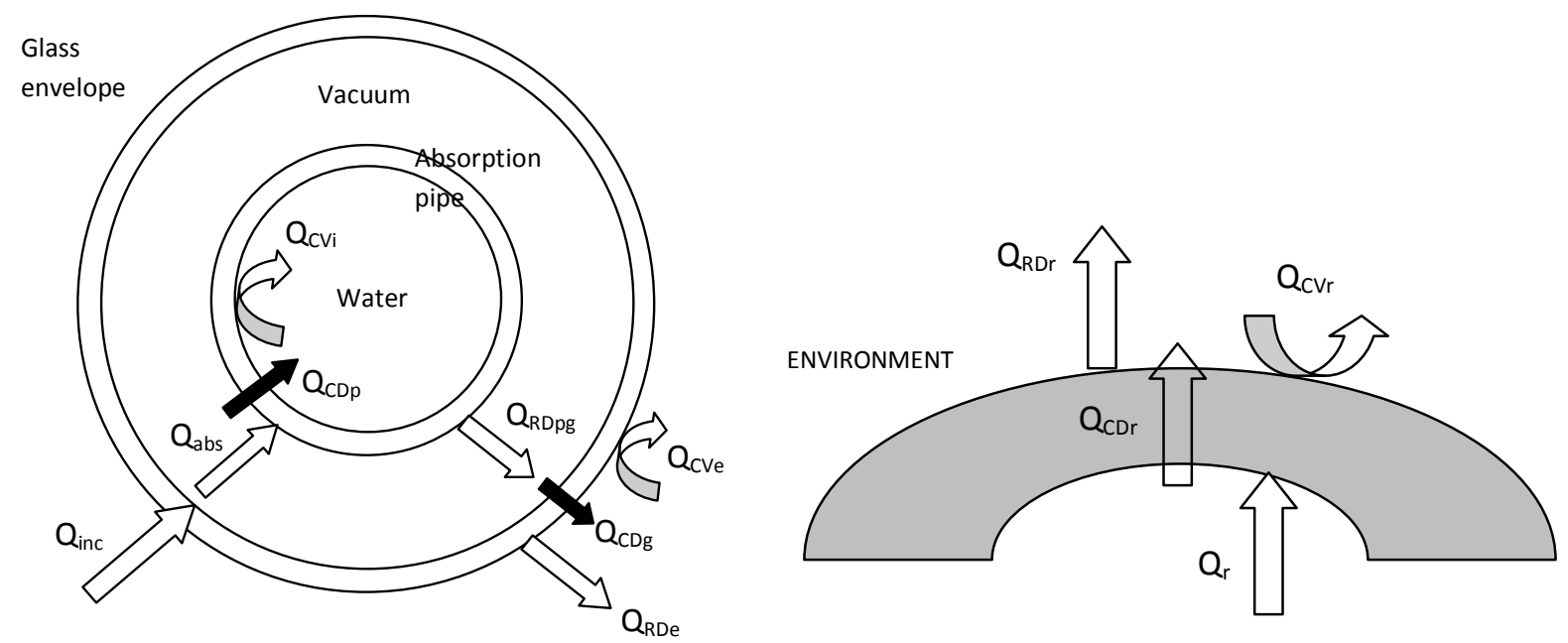

Figure 5. Left: Heat flows in the receptor pipe. Right: Heat flows in secondary reflector.

A power balance is done in the absorption pipe (Eq. 8). Power flow absorbed by pressurized water $\left(\mathrm{Q}_{\mathrm{abs}}\right)$ is equal to solar gains through glass envelope. It is assumed that heat flow absorbed by the water, is equal to solar radiation incident in reception pipe $\left(Q_{\text {inc }}\right)$ minus heat losses $\left(\mathrm{Q}_{\text {loss }}\right)$, see equation 9.

Heat absorbed by water flow is from radiation which arrives at the glass envelope multiplied by: the transmittance of the glass envelope, the transmittance loss factor due to dirtiness of glass envelope, the absorptance of the absorption pipe and the percentage of mirrors in focus, which is obtained from supervision and control system of solar plant. 
Heat losses are calculated as the addition of convective losses to ambient air $\left(\mathrm{Q}_{\mathrm{CVe}}\right)$ and radiant heat exchange between reception pipe, secondary reflector and environment $\left(\mathrm{Q}_{\mathrm{RDe}}\right)$, see equation 10.

$$
\begin{gathered}
Q_{a b s}=\dot{m}_{w} \cdot C p_{w} \cdot\left(T_{w, o u t}-T_{w i n}\right)=Q_{i n e} \cdot \tau_{g} \cdot f_{d i-g} \cdot \alpha_{p} \cdot f_{m i f}(\text { eq. } 8) \\
\left.Q_{a b s}=Q_{i n e}-Q_{\text {loss }} \text { (eq. } 9\right) \\
Q_{l o s s}=Q_{C V e}+Q_{R D \cdot} \text { (eq. 10) }
\end{gathered}
$$

\section{COMPARISON OF RESULTS}

In this section, results from optical and thermal models are compared with plant measured values. Real data is obtained from the Data Acquisition system of the solar cooling plant. Commercial computer programs Matlab and Engineering Equation Solver (EES) are used to solve optical and thermal model respectively. Results for a sunny day are compared: 27th May 2009. In this day, mirrors were clean. In next sections comparison between model results and data from solar plant are presented: Variables considered are: rows inclination angles, stretch of non-lit pipe, output temperature of water and heat absorbed by water at different hours.

\subsection{Inclination angles of mirrors rows}

In table 2, inclination angle of the eleven mirrors rows of FRESNEL collector at different times are shown. For each row and time, the inclination angle is calculated by the optical model, and some measures in solar plant are presented. The presented data was obtained on May, 27th of 2009.

The rows far from line of the reception pipe are more inclined than the rows more centred in the Fresnel collector, due to relative position between row, reception pipe and sun. Also, in table 2, it is shown that inclinations of northern mirror rows (1 to 7) are positive and southern rows (8 to 11$)$ are negative.

The angle errors between calculated and measured values are below $0.3^{\circ}$ independently of mirror row (the average error has a value of $0.17^{\circ}$ ).

\subsection{Stretch of non-lit pipe}

Calculated and measured stretch of non-lit pipe is presented in table 3 for different hours on May 27th. Before solar midday stretch non-lit of reception pipe is in the eastern extreme of it, and after solar midday is in the western extreme. At near midday conditions, the complete reception pipe is illuminated by solar radiation.

It can be seen that calculated values from optical model and measured stretch are similar. 
$2^{\text {nd }}$ European Conference on Polygeneration $-30^{\text {th }}$ March $-1^{\text {st }}$ April 2011 - Tarragona, Spain

\begin{tabular}{|c|c|c|c|c|c|c|c|}
\hline \multicolumn{2}{|c|}{ LOCAL TIME } & 13:00 & $13: 30$ & 14:00 & $14: 30$ & $15: 00$ & $15: 30$ \\
\hline \multicolumn{2}{|c|}{ SOLAR TIME } & $10: 39$ & $11: 09$ & $11: 39$ & $12: 09$ & $12: 39$ & $13: 09$ \\
\hline \multirow{2}{*}{ ROW 1} & $\operatorname{CALC}\left(^{\circ}\right)$ & 25.9 & 27.1 & 28.0 & 28.8 & 29.3 & 29.7 \\
\hline & $\operatorname{MEAS}\left({ }^{\circ}\right)$ & 25.7 & 27.0 & 27.7 & 28.6 & 29.2 & 29.6 \\
\hline \multirow{2}{*}{ ROW 2} & $\operatorname{CALC}\left({ }^{\circ}\right)$ & 22.8 & 24.0 & 24.9 & 25.7 & 26.2 & 26.7 \\
\hline & $\operatorname{MEAS}\left({ }^{\circ}\right)$ & 22.5 & 23.8 & 24.6 & 25.5 & 26.1 & 26.5 \\
\hline \multirow{2}{*}{ ROW 3} & $\operatorname{CALC}\left(^{\circ}\right)$ & 19.2 & 20.4 & 21.3 & 22.0 & 22.6 & 23.1 \\
\hline & $\operatorname{MEAS}\left({ }^{\circ}\right)$ & 19.0 & 20.2 & 21.1 & 21.8 & 22.4 & 22.8 \\
\hline \multirow{2}{*}{ ROW 4} & $\operatorname{CALC}\left({ }^{\circ}\right)$ & 15.0 & 16.2 & 17.1 & 17.8 & 18.4 & 18.8 \\
\hline & $\operatorname{MEAS}\left({ }^{\circ}\right)$ & 14.7 & 16.0 & 16.8 & 17.6 & 18.2 & 18.6 \\
\hline \multirow{2}{*}{ ROW 5} & $\operatorname{CALC}\left({ }^{\circ}\right)$ & 10.3 & 11.5 & 12.4 & 13.1 & 13.7 & 14.1 \\
\hline & $\operatorname{MEAS}\left({ }^{\circ}\right)$ & 10.1 & 11.3 & 12.2 & 13.0 & 13.5 & 13.9 \\
\hline \multirow{2}{*}{ ROW 6} & $\operatorname{CALC}\left({ }^{\circ}\right)$ & 5.3 & 6.5 & 7.4 & 8.2 & 8.7 & 9.2 \\
\hline & $\operatorname{MEAS}\left({ }^{\circ}\right)$ & 5.0 & 6.4 & 7.2 & 8.0 & 8.5 & 9.0 \\
\hline \multirow{2}{*}{ ROW 7} & $\operatorname{CALC}\left({ }^{\circ}\right)$ & 0.4 & 1.5 & 2.5 & 3.2 & 3.8 & 4.2 \\
\hline & $\operatorname{MEAS}\left({ }^{\circ}\right)$ & 0.1 & 1.4 & 2.2 & 3.1 & 3.7 & 4.1 \\
\hline \multirow{2}{*}{ ROW 8} & $\operatorname{CALC}\left({ }^{\circ}\right)$ & -4.3 & -3.1 & -2.2 & -1.5 & -0.9 & -0.5 \\
\hline & $\operatorname{MEAS}\left({ }^{\circ}\right)$ & -4.6 & -3.2 & -2.5 & -1.7 & -1.1 & -0.6 \\
\hline \multirow{2}{*}{ ROW 9} & $\operatorname{CALC}\left({ }^{\circ}\right)$ & -8.5 & -7.3 & -6.4 & -5.7 & -5.1 & -4.7 \\
\hline & $\operatorname{MEAS}\left({ }^{\circ}\right)$ & -8.7 & -7.5 & -6.7 & -5.7 & -5.3 & -4.8 \\
\hline \multirow{2}{*}{ ROW 10} & $\operatorname{CALC}\left(^{\circ}\right)$ & -12.1 & -11.0 & -10.1 & -9.3 & -8.7 & -8.3 \\
\hline & $\operatorname{MEAS}\left({ }^{\circ}\right)$ & $-12,4$ & $-11,2$ & -10.0 & -9.4 & -8.9 & -8.5 \\
\hline \multirow{2}{*}{ ROW 11} & $\operatorname{CALC}\left({ }^{\circ}\right)$ & -15.4 & -14.1 & -13.2 & -12.4 & -11.8 & -11.4 \\
\hline & $\operatorname{MEAS}\left({ }^{\circ}\right)$ & -15.5 & -14.3 & -13.4 & -12.5 & -12.0 & -11.6 \\
\hline
\end{tabular}

Table 2. Inclination calculated and measured angles the day May $27^{\text {th }} 2009$ (Day 147).

\begin{tabular}{|c|c|c|c|}
\hline $\begin{array}{c}\text { LOCAL } \\
\text { TIME }\end{array}$ & $\begin{array}{c}\text { SOLAR } \\
\text { TIME }\end{array}$ & $\begin{array}{c}\text { Calculated } \\
\text { N.L.P. }(\mathbf{m})\end{array}$ & $\begin{array}{c}\text { Measured } \\
\text { N.L.P. } \\
(\mathbf{m})\end{array}$ \\
\hline $13: 00$ & $10: 39$ & $1.6 \mathrm{E}$ & $1.5 \mathrm{E}$ \\
\hline $13: 30$ & $11: 09$ & $1.1 \mathrm{E}$ & $0.9 \mathrm{E}$ \\
\hline $14: 00$ & $11: 39$ & $0.6 \mathrm{E}$ & $0.4 \mathrm{E}$ \\
\hline $14: 30$ & $12: 09$ & $0.1 \mathrm{~W}$ & $0.1 \mathrm{~W}$ \\
\hline $15: 00$ & $12: 39$ & $0.4 \mathrm{~W}$ & $0.5 \mathrm{~W}$ \\
\hline $15: 30$ & $13: 09$ & $0.9 \mathrm{~W}$ & $1.0 \mathrm{~W}$ \\
\hline
\end{tabular}

Table 3. Calculated and measured stretch of non-lit pipe the day May $27^{\text {th }} 2009$.

\subsection{Thermal model}

To quantify solar radiation incident onto reception pipe, it is necessary to define the dirtiness factor for the primary reflector, the secondary reflector and the glass envelope of the reception pipe, as well as the percentage of mirrors in focus. For the selected experimentation day, all factors have a value of 1 because mirrors were cleaned two days before experimentation day. 
Percentage of mirrors in focus can be obtained from supervision and control system of solar plant at any time. It depends directly on the set point of maximum water temperature output, which is fixed in the control system.

Table 4 shows the results of the thermal model for different times. For each time is presented: water mass flow, water pressure in pipe, ambient temperature, percentage of mirrors in focus, beam radiation incident in the reception pipe (calculated using optical model), water input temperature, heat absorber by water (calculated using thermal model and measured), output water temperature (calculated using thermal model and measured).

\begin{tabular}{|c|c|c|c|c|c|c|c|c|c|c|c|}
\hline $\begin{array}{c}\text { LOCAL } \\
\text { TIME }\end{array}$ & $\begin{array}{c}\text { SOLAR } \\
\text { TIME }\end{array}$ & $\begin{array}{c}\text { FLOW } \\
\left(\mathbf{m}^{\mathbf{3}} / \mathbf{h}\right)\end{array}$ & $\begin{array}{c}\text { PRESS. } \\
(\mathbf{b a r})\end{array}$ & $\begin{array}{c}\text { EXT. } \\
\text { TEMP. } \\
\left({ }^{\circ}\right)\end{array}$ & $\begin{array}{c}\text { \% } \\
\text { MIRRORS } \\
\text { IN FOCUS }\end{array}$ & $\begin{array}{c}\text { RAD. } \\
(\mathbf{k W})\end{array}$ & $\begin{array}{c}\text { INLET. } \\
\text { TEMP. } \\
\left({ }^{\circ}\right)\end{array}$ & $\begin{array}{c}\text { CALC. } \\
\text { OUTLET } \\
\text { TEMP. } \\
\left({ }^{\circ}\right)\end{array}$ & $\begin{array}{c}\text { MEAS. } \\
\text { OUTLET } \\
\text { TEMP. } \\
\left({ }^{\circ}\right)\end{array}$ & $\begin{array}{c}\text { CALC. } \\
\mathbf{Q}_{\text {ABS }} \\
(\mathbf{k W})\end{array}$ & $\begin{array}{c}\text { MEAS. } \\
\mathbf{Q} \text { (ABS } \\
(\mathbf{k W})\end{array}$ \\
\hline $13: 00$ & $10: 39$ & 10.1 & 11.1 & 27.5 & 100.0 & 149.9 & 137.2 & 147.0 & 145.9 & 108 & 102 \\
\hline $13: 30$ & $11: 09$ & 10.5 & 11.3 & 28.8 & 100.0 & 152.3 & 142.3 & 151.8 & 151.2 & 110 & 109 \\
\hline $14: 00$ & $11: 39$ & 12.2 & 11.8 & 29.0 & 96.7 & 148.9 & 158.5 & 166.2 & 165.2 & 106 & 96 \\
\hline $14: 30$ & $12: 09$ & 12.2 & 11.8 & 29.5 & 83.6 & 127.8 & 158.9 & 165.8 & 166.0 & 93 & 100 \\
\hline $15: 00$ & $12: 39$ & 12.8 & 12.0 & 30.1 & 57.1 & 88.5 & 169.4 & 173.9 & 173.8 & 63 & 65 \\
\hline $15: 30$ & $13: 09$ & 12.2 & 11.8 & 31.0 & 68.6 & 105.4 & 162.8 & 168.5 & 169.4 & 77 & 93 \\
\hline
\end{tabular}

Table 4. Calculation of outlet temperature the day May $27^{\text {th }} 2009$.

When experimental data is compared with simulated data, it can be observed that:

- Differences between simulated and real heat absorbed by water are lower by $7 \%$.

- Error between measured data and calculated results are less than $1 \%$ when output temperature is considered.

These are acceptable errors taking into account assumptions made with dirtiness loss factors.

During the experiment, the reception pipe had an average efficiency of $72 \%$.

\section{CONCLUSIONS}

This paper outlines the development of a theoretical model to describe optically and thermally a linear Fresnel collector system. Model results have been compared with real values measured from a solar cooling plant with absorption chiller located in the Engineering School of Seville. It has been observed that the calculated values are in good agreement with the measured values. As the model calculates solar power based on location and time, the model can be used to model the performance of this Fresnel collector system at any location.

The small differences between calculated values and measured values are a result of several factors:

- Equations relating to transitory regime in heat transfer have not been included

- Continuous focus and non-focus of mirrors when the maximum output temperature is reached

- Dirtiness of the elements of the system 
$2^{\text {nd }}$ European Conference on Polygeneration $-30^{\text {th }}$ March $-1^{\text {st }}$ April 2011 - Tarragona, Spain

\section{Nomenclature}

$\vec{\imath}: \quad$ Solar incidence vector $\left[{ }^{\circ}\right]$

$\dot{m}$ : Water mass flow $[\mathrm{kg} / \mathrm{s}]$

$\vec{n}: \quad$ Normal vector

$\vec{r}: \quad$ Solar reflection vector $\left[{ }^{\circ}\right]$

A: $\quad$ Area of surface $\left[\mathrm{m}^{2}\right]$

Azi: Solar azimuth angle $\left[{ }^{\circ}\right]$

BR: Beam radiation $\left[\mathrm{W} / \mathrm{m}^{2}\right]$

Cp: Specific heat, constant pressure $\left[\mathrm{J} /\left(\mathrm{kg} \cdot{ }^{\circ} \mathrm{C}\right)\right]$

Ele: $\quad$ Solar elevation angle $\left[{ }^{\circ}\right]$

f: $\quad$ Factor

IA: real radiation which arrives at glass from the mirrors [W]

incl: Inclination angle of mirror row $\left[^{\circ}\right]$

Orientation: Deviation angle of the solar field with regard to South $\left[^{\circ}\right]$

Q: $\quad$ Power flow [W]

T: $\quad$ Temperature $\left[{ }^{\circ} \mathrm{C}\right]$

\section{Greek Symbols}

$\alpha$ : Absorptance

$\delta$ : Angle between normal vector row and $\mathrm{Y}$ axe $\left[^{\circ}\right]$
0: $\quad$ Angle formed by incidence vector and normal vector; angle formed by normal vector and reflection vector $\left[^{\circ}\right]$

$\rho: \quad$ Reflectance

$\tau: \quad$ Transmittance

$\gamma$ : Angle formed by incidence vector and horizontal axis $\left[{ }^{\circ}\right]$

$\begin{array}{ll}\text { Subscripts } \\ \text { calc: } & \text { Calculated result } \\ \text { CV: } & \text { Convective } \\ \text { dl: } & \text { Dirtiness loss } \\ \text { env: : } & \text { Environment } \\ \text { g: } & \text { Glass envelope } \\ \text { in: } & \text { Input } \\ \text { Inc: } & \text { Incident } \\ \text { mea: } & \text { Measured data } \\ \text { mif: } & \text { Mirror in focus } \\ \text { nlp: } & \text { Non-lit pipe } \\ \text { out: } & \text { Output } \\ \text { pr: } & \text { Primary reflectors } \\ \text { RD: } & \text { Radiant } \\ \text { shading: Shadowing between mirror rows } \\ \text { sr: } \quad \text { Secondary reflector } \\ \text { w: } \quad \text { Water }\end{array}$

\section{References}

[1] P. Bermejo, F.J. Pino, F. Rosa, S. Álvarez, M. Beltrán, Solar Absorption Cooling Plant in Seville, 3rd International Conference Solar Air-Conditioning, Palermo, 2009.

[2] Häberle A., Berger M., Luginsland F., Zahler C., Baitsch M., Henning H.M., Rommel M. "Linear concentrating Fresnel collector for process heat applications". http://www.pse.de

[3] SCHOTT. SCHOTT PTRTM70 Receiver for solar thermal power plants. http://www.schott.com

[4] Mills D.R. and Morrison G.L. (2000) Compact linear Fresnel reflector solar thermal powerplants. Solar Energy 68, 263-283.

[5] Chong K.K. and Wong C.W. (2009) General formula for on-axis sun-tracking system and its application in improving tracking accuracy of solar collector. Solar Energy 83, 298-305.

[6] Castro Gil, M.A. (1988) Simulación de Centrales de Energía Solar. Aplicación a la Gestión Energética.

[7] El Fadar A., Mimet A., Azzabakh A., Pérez García M. and Castaing J. (2009) Study of a new solar adsorption refrigerator powered by a parabolic trough collector. Applied Thermal Engineering 29, 1267-1270. 
$2^{\text {nd }}$ European Conference on Polygeneration $-30^{\text {th }}$ March $-1^{\text {st }}$ April 2011 - Tarragona, Spain

[8] Thomas A. and Guven H.M. (1993) Parabolic trough concentrators - Design, construction and evaluation. Energy Conversion and Management 34, 401-416.

[9] Pablo Bermejo, Francisco Javier Pino, Felipe Rosa (2010), Solar absorption cooling plant in Seville, Solar Energy 84, 1503-1512

[10] Incropera F.P. and DeWitt D.P. (1999) Fundamentals of Heat Transfer. Ed. Wiley.

[11] Odeh S.D., Morrison G.L. and Behnia M. (1998) Modelling of parabolic through direct steam generation solar collectors. Solar Energy 62, 395-406.

[12] Mills D.R., Monger A. and Morrison G.L. (1994) Comparison of fixed asymmetrical and symmetrical reflectors for evacuated tube solar receivers. Solar Energy 53, 91-104.

[13] García-Valladares O. and Velázquez N. (2009) Numerical simulation of parabolic trough solar collection: Improvement using counter flow concentric circular heat exchangers. International Journal of Heat and Mass Transfer 52, 597-609.

[14] Rolim M.M., Fraidenraich N. and Tiba C. (2009) Analytic modeling of a solar power plant with parabolic linear collectors. Solar Energy 83, 126-133.

\section{Acknowledgements}

Experimental validation of this model has been carried out thanks to the solar cooling plant with an absorption chiller, which is located in the Engineering School of Seville. This facility belongs to a project currently being carried out by Gas Natural and cofinanced by Corporación Tecnológica de Andalucía and Agencia de Innovación de Andalucia (IDEA). 